\title{
Atresia Ani in Dogs and Cats
}

\author{
Lysimachos G. Papazoglou' ${ }^{1}$ and Gary W. Ellison² \\ ${ }^{1}$ Department of Clinical Sciences, Faculty of Veterinary Medicine, \\ Aristotle University of Thessaloniki, \\ ${ }^{2}$ Department of Small Animal Clinical Sciences, Health Science Center, \\ University of Florida Gainesville, \\ ${ }^{1}$ Greece \\ 2USA
}

\section{Introduction}

Congenital deformities of the anorectum are rarely encountered in small animals with atresia ani being the most common one. Atresia ani is a congenital defect of the anorectum, resulting in anal canal closure and /or abnormal routing of feces (Bright \& Bauer, 1994). Among large animals congenital atresia ani most often occurs in pigs and calves and is considered hereditary. In these species atresia may be seen as a separate entity or in conjunction with other malformations of the distal vertebral column, urogenital tract and sometimes with intestinal atresia or colonic agenesis (Kilic \& Sariepler, 2004; Maxie, 2007). In pigs atresia is associated with a high mortality rate but selective breeding decreased its occurrence (Partlow et al., 1993; Viana \&Tobias, 2005).

\section{Epidemiology}

Atresia ani is uncommonly described in dogs and it is even less frequently reported in cats; the true incidence of this abnormality is difficult to determine and may be greater than reported because many newborn puppies and kittens are euthanatized before being evaluated based on the hypothesis that surgical correction is unsuccessful; additionally unpublished data may hide true prevalence as complications associated with surgical correction of these deformities are common (Prassinos et al.,. 2003; Mahler \& Williams, 2005; Viana \& Tobias, 2005). According to a review of Veterinary Medical Database atresia ani in dogs accounts for 0.0007 with females more likely to be affected than males (female/male $=1.79 / 1$ ) [Viana \& Tobias, 2005]. Canine breeds overpresented include Finish spitz, Boston teriers, Maltese, chow chow, German shorthair pointer, toy poodle and miniature schnauzer (Viana \& Tobias, 2005). In cats females are more commonly affected than males (Suess et al., 1992; van de Broek et al., 1988; Tsioli et al., 2009, Tomsa et al., 2011).

\section{Normal and abnormal embryologic development}

The embryologic development of the canine and feline anorectum resembles that of the human development (Greiner, 1972; Amand, 1974; Suess et al., 1992; Sadler, 1995; Viana \& 
Tobias, 2005). The cloaca is a common route for gastrointestinal and urogenital tracts in the canine and feline embryo. Retention of the cloaca occurs in vertebrate animals other than placental mammals; in higher mammals the cloaca separates during embryologic development. By the seventh to eighth week of development the urorectal fold, which located between the allantois and the hindgut openings in the cloaca, initially divides the cloaca into the dorsal part called the rectum and the ventral part called the urogenital sinus (Figures 1 \&2). The urogenital sinus is further differentiated into the urethra and the urinary bladder. The terminal end of the hindgut forms the cranial anal canal and the anus is formed at a later time by ectodermal ingrowth of the perineum. A breakdown in physiological embryologic differentiation of the cloacal region may lead to a variety of congenital malformations of the anorectum. Failure of the urorectal fold to divide the cloaca completely or failure of the anal membrane to rupture after anal creation results in atresia ani.

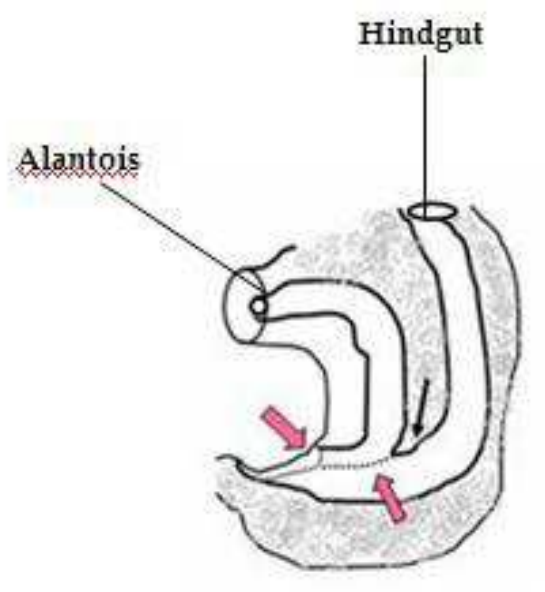

Fig. 1. Urorectal fold (arrows) located between the alantois and hindgut by 7 th to $8^{\text {th }}$ week of development.

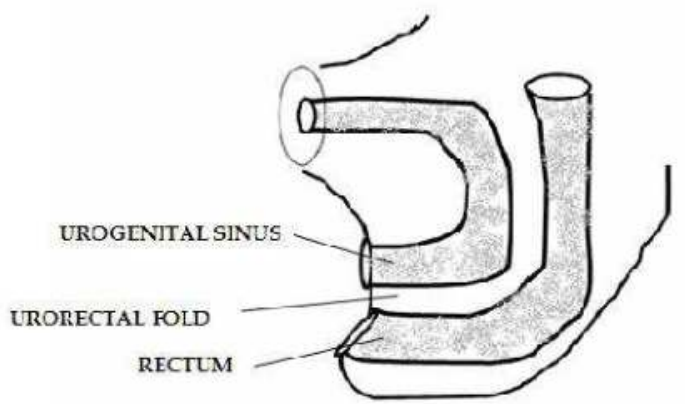

Fig. 2. The cloaca is divided into urorectal sinus and rectum. 


\section{Classification}

Four anatomic types of atresia ani have been described in dogs and cats (Aronson, 2003; Viana \&Tobias, 2005; Ellison \& Papazoglou, 2011) [Figures 3-7].

External anal sphincter and anal sacs are usually develop normally in type II anomalies (Seim, 1986; Ellison \& Papazoglou, 2011), while agenesis of the external anal sphincter, anal sacs or tail are reported in type III anomalies (Rawlings \& Capps, 1971; Knecht \& Westerfield, 1971; Loug \& van Schouwenburg, 1982; Ellison \& Papazoglou, 2011). Occasionally dogs and more rarely cats with type II and more uncommonly with type III atresia ani may be associated with rectovaginal, rectovestibular or urethrorectal fistulas (Holt, 1985; van den Broek et al., 1988; Chandler \& MacPhail, 2001; Aronson, 2003; Ellison \& Papazoglou, 2011). Animals with type III atresia ani associated with rectovaginal fistula are also reported as having an ectopic anus (Prassinos et al., 2003). However, it is unclear if type IV atresia ani has ever been reported in dogs and cats (Ellison \& Papazoglou, 2011).

\begin{tabular}{|l|l|}
\hline Atresia Type & Anomaly \\
\hline Type I & Congenital stenosis of a patent anus \\
\hline Type II & $\begin{array}{l}\text { Persistence of a complete anal membrane } \\
\text { alone or a combination of an anal } \\
\text { membrane with the rectum ending as a } \\
\text { blind pouch cranial to the membrane. }\end{array}$ \\
\hline Type III & $\begin{array}{l}\text { Presence of an imperforate anus with the } \\
\text { rectum terminating further cranially. }\end{array}$ \\
\hline Type IV & $\begin{array}{l}\text { Normal ending of the terminal rectum and } \\
\text { anus while the cranial rectum terminates as } \\
\text { a blind pouch within the pelvis. }\end{array}$ \\
\hline
\end{tabular}

Table 1. Anatomic types of atresia ani in dogs and cats

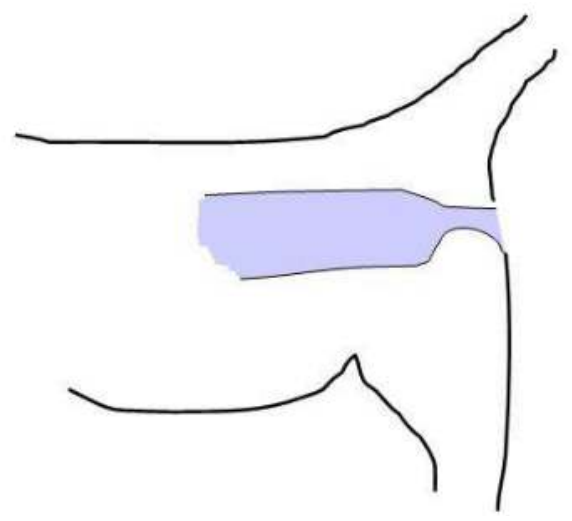

Fig. 3. Schematic representation of type I atresia ani. 


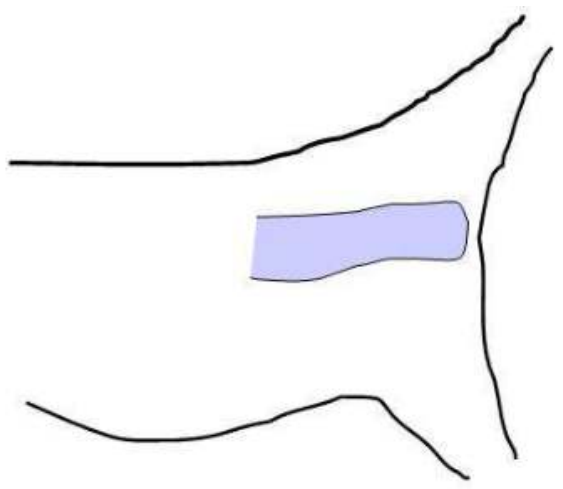

Fig. 4. Schematic representation of type II atresia ani.

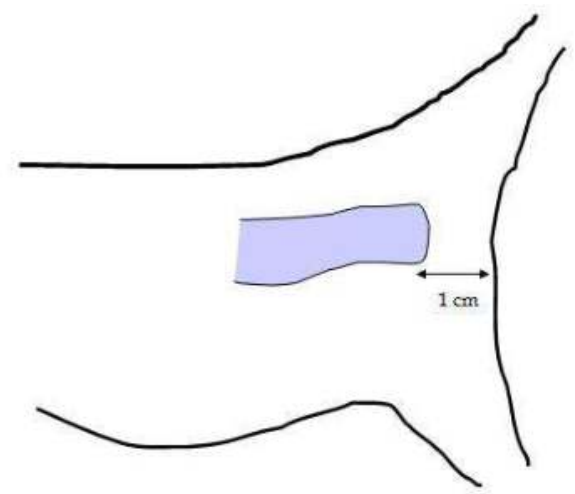

Fig. 5. Schematic representation of type III atresia ani. The blind rectal pouch is more than 1 $\mathrm{cm}$ away from the anal dimple.

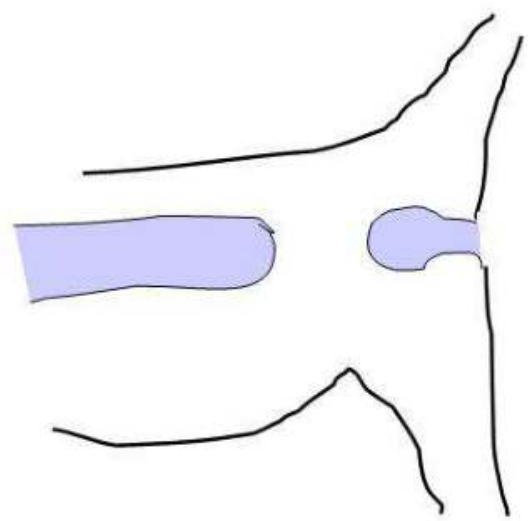

Fig. 6. Schematic representation of type III atresia ani. It is not clear if this type of atresia has been reported in small animals. 


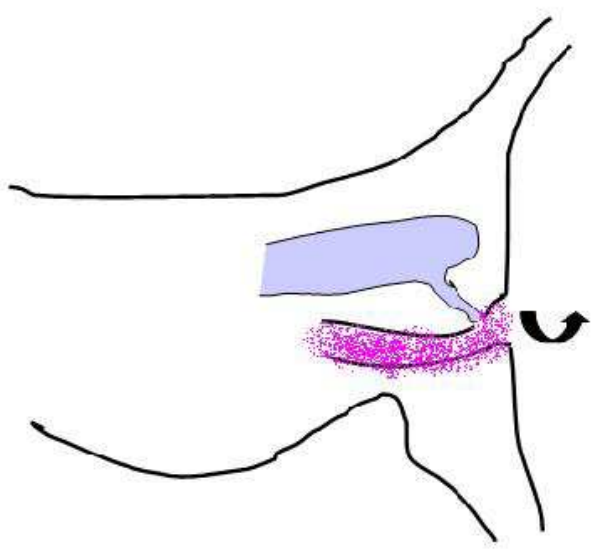

Fig. 7. Schematic representation of type II atresia ani combined with rectovaginal fistula.

\section{History and clinical signs}

A history of absence of defecation, which sometimes may go unnoticed, is reported. Clinical signs of atresia ani are usually evident within a few weeks of birth and depend on the type of atresia (Aronson, 2003; Viana \&Tobias, 2005; Ellison \& Papazoglou, 2011). Animals with type I atresia ani may exhibit constipation and tenesmus soon after weaning (Figure 8). A stenosed anal opening is evident on digital rectal palpation. Puppies and kittens belonging to types II, III and IV are clinically normal for the first 2 to 4 weeks of birth. A history of anorexia, depression, absence of defecation, tenesmus and abdominal distention are reported to follow this time frame (Figure 9). Physical examination may also reveal a dimple at the site of the closed anal opening (Figures 10 \&11), abdominal enlargement, discomfort on abdominal palpation and perineal swelling depending on the type of anomaly. Abdominal enlargement may be attributed to colonic distention with feces or gas, fecal impaction or even megacolon. Longstanding cases may develop vomiting and dehydration. Animals with rectovaginal or rectourethral communications often show passage of watery to formed feces through the vagina or urethra; these animals may be in better physical condition that others with no rectovaginal or rectourethral communications (Prassinos et al., 2003; Rahal et al., 2007) [Figure 12]. Multiple congenital anomalies such as umbilical hernias, cleft palates, open fontanels, hypospadias, tail agenesis and deafness in dogs and sacrocaudal dysgenesia and hydrocepahalus in kittens may accompany atresia ani and should not escape a thorough physical or other diagnostic examination (Suess et al., 1992; Aronson, 2003; Prassinos et al., 2003; Rahal et al., 2007; Ellison \& Papazoglou, 2011) [Figure 13]. Rectocutaneous fistulas associated with type II atresia ani have been recently reported in a cat (Tsioli et al., 2009) [Figure 14]. 


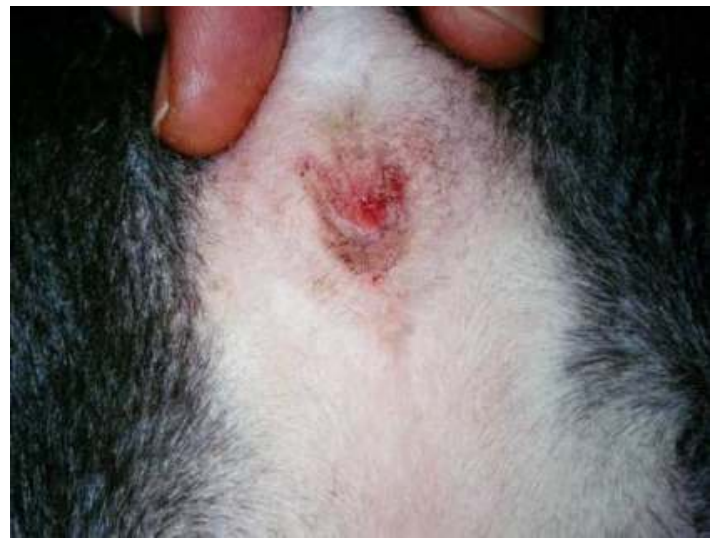

Fig. 8. Atresia ani type I in a mixed breed puppy.

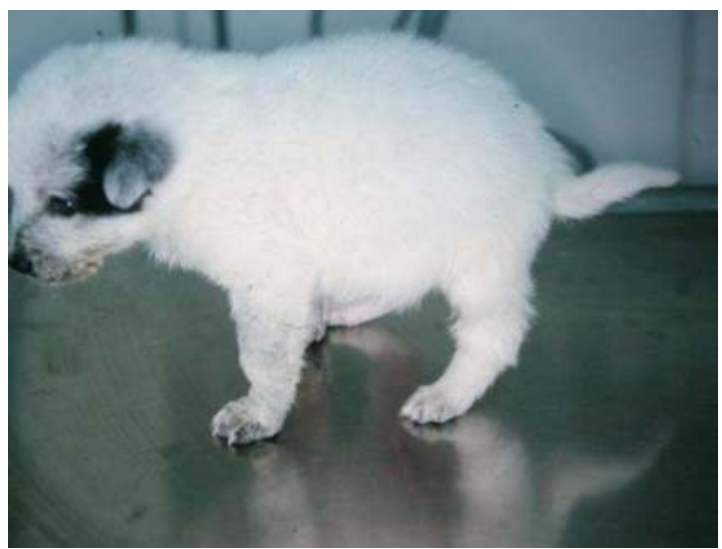

Fig. 9. A mixed breed puppy with abdominal distention associated with type II atresia ani.

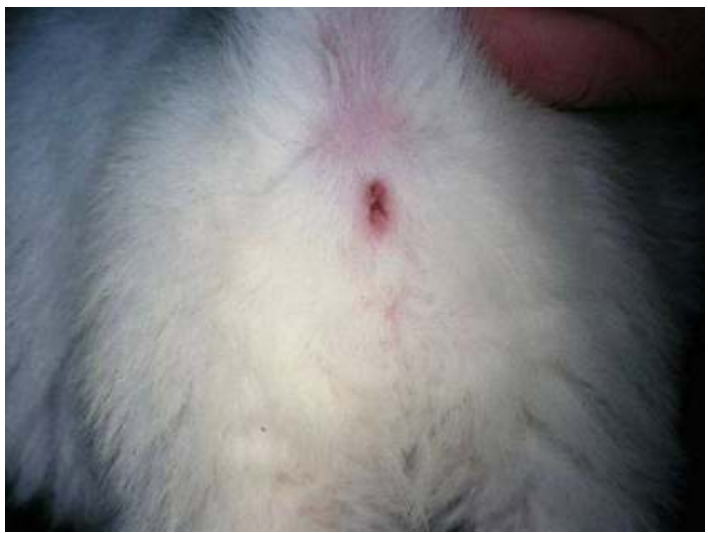

Fig. 10. Atresia ani type II of the dog of figure 9. 


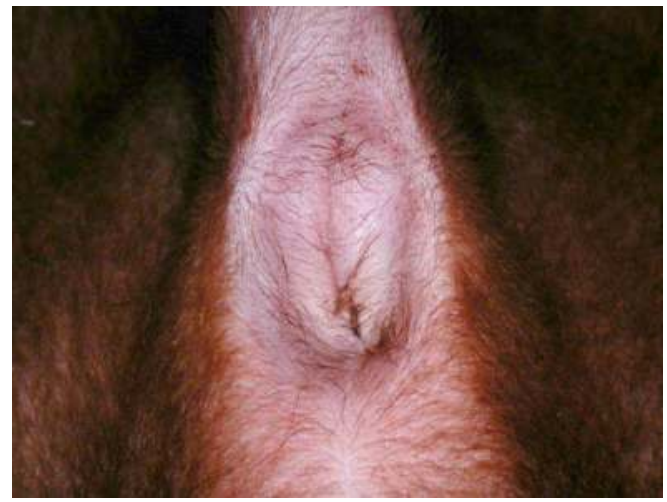

Fig. 11. An anal dimple associated with type II atresia ani in a dog.

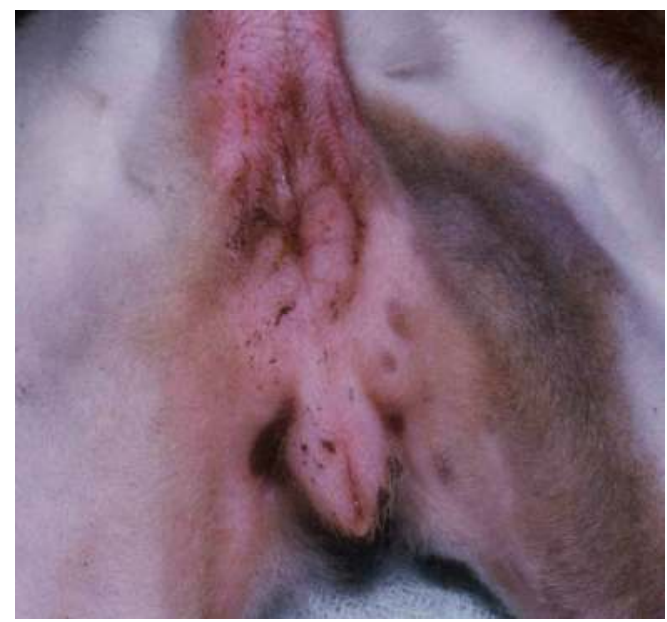

Fig. 12. Atresia ani type II associated with rectovaginal fistula in a puppy.

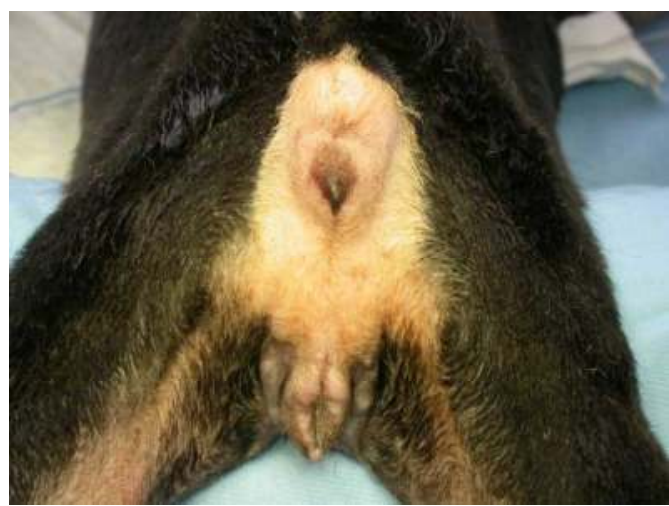

Fig. 13. Atresia ani type III associated with rectovaginal fistula and tail agenesis in a puppy. 


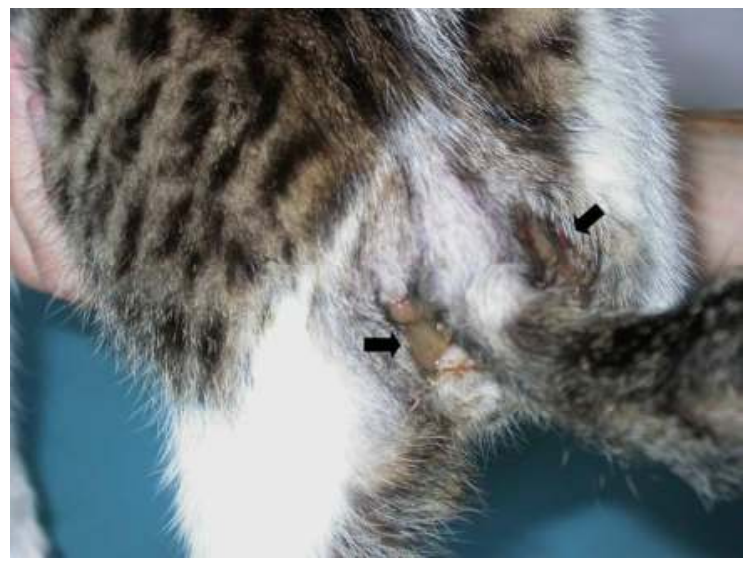

Fig. 14. Rectocutaneous fistulas ventral and lateral to the tail (arrows) in a cat with type II atresia ani

\section{Diagnosis}

Diagnosis of atresia ani is based in clinical signs, physical examination findings and confirmed with radiographic examination. Evaluation of external anal sphincter muscle presence and function is important for prognostic purposes.

\subsection{Diagnostic tests}

Penile bulb or vulva pinching may result in an anal wink (bulbourethral reflex) [Chambers, 1986; Hosgood \& Hoskins, 1998]. Electro stimulation of perineal muscles using electrocautery at surgery or nerve stimulators may also be used to check for a strong anal response (Mahler \& Williams, 2005). Electromyography for external anal sphincter muscle may be used if available for a more accurate evaluation of the anal tone (Ellison \& Papazoglou, 2011).

\subsection{Radiographic examination}

Abdominal radiography is useful in atresia ani anatomic typing and ruling out colonic distention, which may lead in megacolon that affects management and prognosis (Figures 15-18). Gas accumulation in colon and rectum, as visualized in plain radiographs, may help in determining the position of the terminal rectum. Horizontal beam abdominal radiographs with the animal suspended upside down and pressure around the abdomen may help to visualize gas accumulation migrating to the terminal colon and rectum and outlining the borders of the rectal pouch (Greiner, 1972; Bright \& Bauer, 1994). Additionally, a coin is placed at the anal dimple to help outline the anus (Greiner et al., 1984). In case of rectovaginal or urethrorectal fistulation positive contrast vaginography or urethrography may help determine fistula and terminal rectum location (Aronson, 2003; Prassinos et al., 2003; Viana \&Tobias, 2005; Rahal et al., 2007; Ellison \& Papazoglou, 2011). 


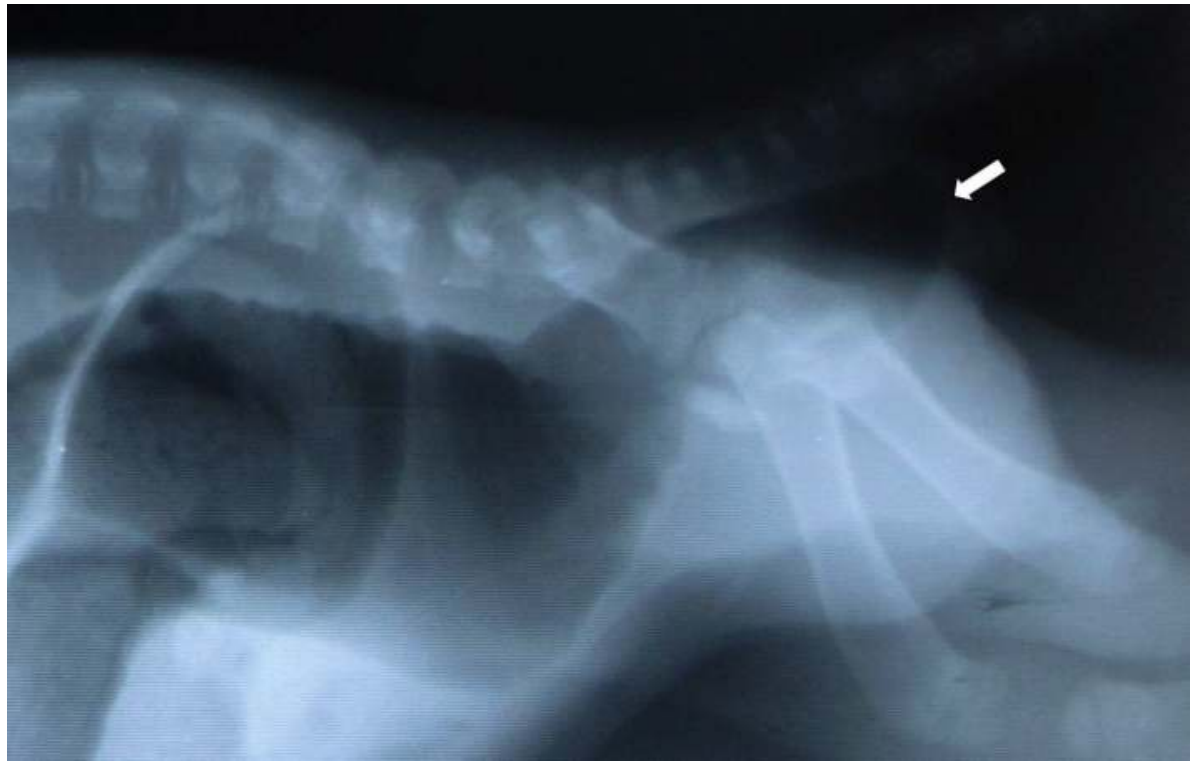

Fig. 15. Abdominal radiograph of a dog visualizing gas accumulation in the colon and rectum. The location of the terminal rectum is also shown (arrow) [Courtesy Dr. M.N. Patsikas, Aristotle University of Thessaloniki].

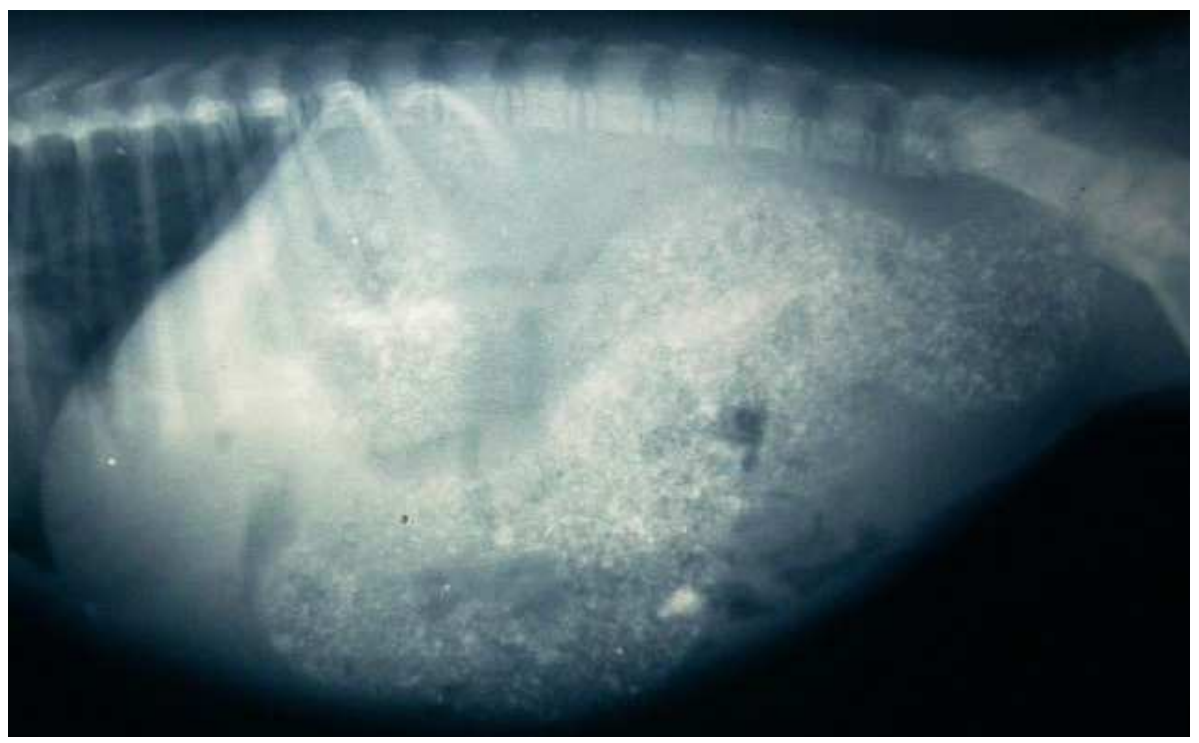

Fig. 16. Abdominal radiograph showing megacolon associated with type II atresia ani in a dog (Courtesy Dr. M.N. Patsikas, Aristotle University of Thessaloniki). 


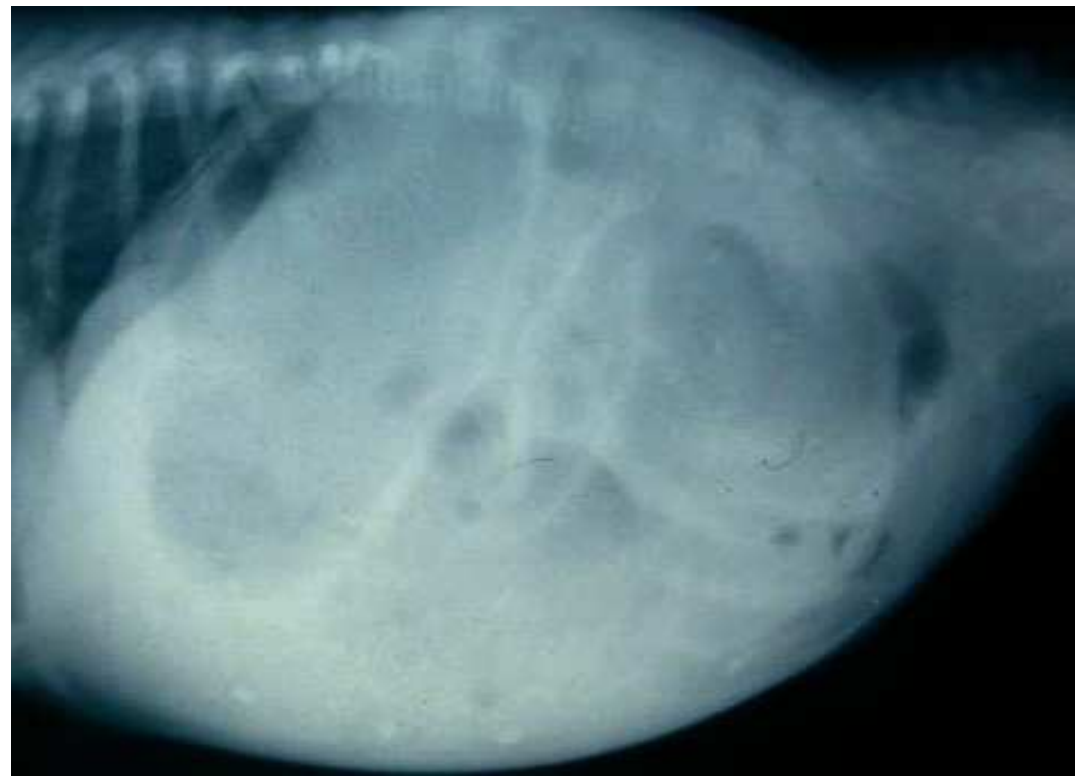

Fig. 17. Abdominal radiograph of a boxer puppy depicting colonic gas distention associated with type II atresia ani (Courtesy Dr. M.N. Patsikas, Aristotle University of Thessaloniki).

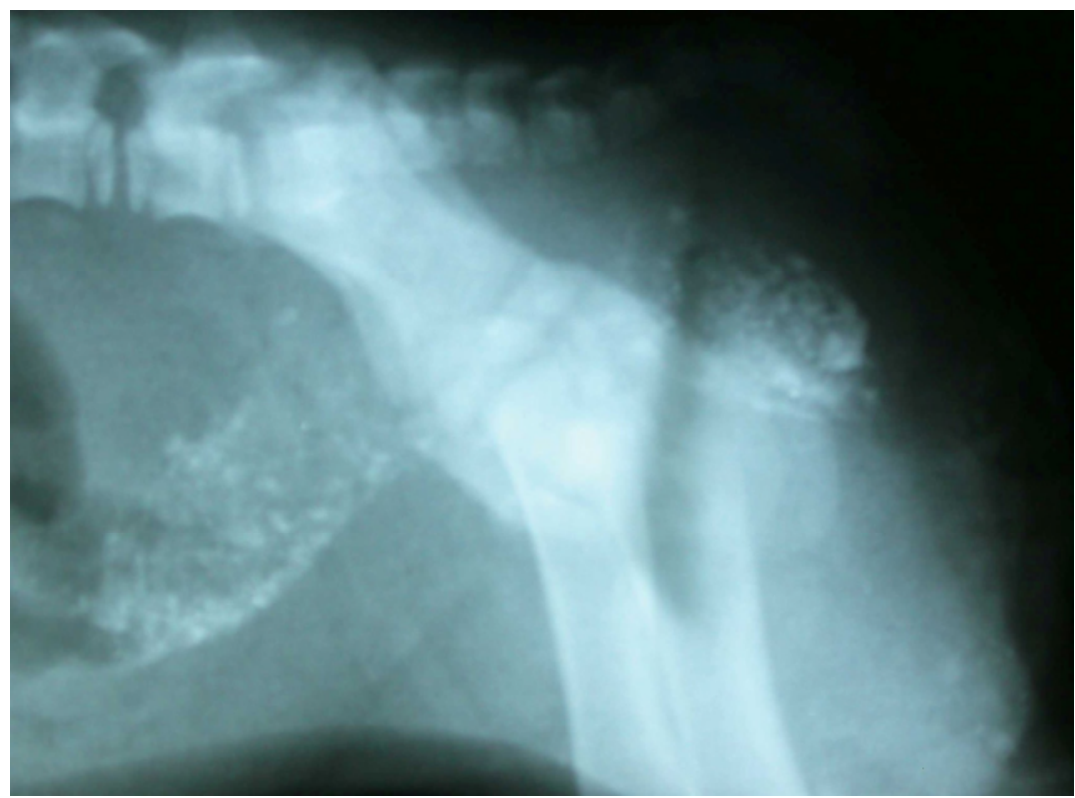

Fig. 18. Abdominal radiograph of a female rottweiler cross puppy with type III atresia ani and rectovaginal fistula showing fecal material in the colon, terminal rectum and over the vagina level. (Courtesy Dr. M.N. Patsikas, Aristotle University of Thessaloniki). 


\section{Treatment}

Surgical correction is considered the only treatment for atresia ani. Anatomical typing of atresia ani should be performed to help determining the type of surgical correction for each case (Ellison \& Papazoglou, 2011). However, non surgical management may also be applied for type I cases (Tomsa et al., 2011; Ellison \& Papazoglou, 2011). Numerous case reports have appeared in the literature reporting surgical treatment of atresia ani in dogs and cats. Currently there are only 3 small and 1 larger case series reporting surgical treatment in dogs (Prassinos et al., 2003; Vianna \& Tobias, 2005; Rahal et al., 2007) and 2 small case series in cats describing surgical or medical management of atresia ani (Suess et al., 1992; Tomsa et al., 2011). Anoplasty is the most common procedure performed. The aim of surgery is to restore anorectal continuity, to preserve the external anal sphincter, to preserve or restore colonic function and to eliminate any rectovaginal or urethrorectal communication. Surgical treatment should be prompt and performed before colonic atony or megacolon associated with chronic and prolonged distention or possible urinary tract infection ensues (Prassinos et al., 2003). Animals with atresia ani type II and III that are unable to defecate if not treated surgically will die because of bowel stasis. End-on temporary colostomy may be considered as an option for the treatment of cats with rectocutaneous fistulas associated with atresia ani (Tsioli et al., 2009). The perineal approach is used for all surgical corrections of atresia types I-III. Prophylactic antibiotics (cefoxitin $20 \mathrm{mg} / \mathrm{kg}$ ) are administered intravenously at anesthetic induction.

\subsection{Type I atresia ani}

Animals with this type of atresia ani are placed in ventral decumbency and treated with resection of the strictured portion of the rectum through a $360^{\circ}$ anoplasty. After excision of the stricture the rectal mucosa is brought distally so as mucosa to skin apposition is achieved with simple interrupted sutures using synthetic non absorbable monofilament 4/0$5 / 0$ suture material (Figure 19). Care is taken during dissection to preserve the external anal

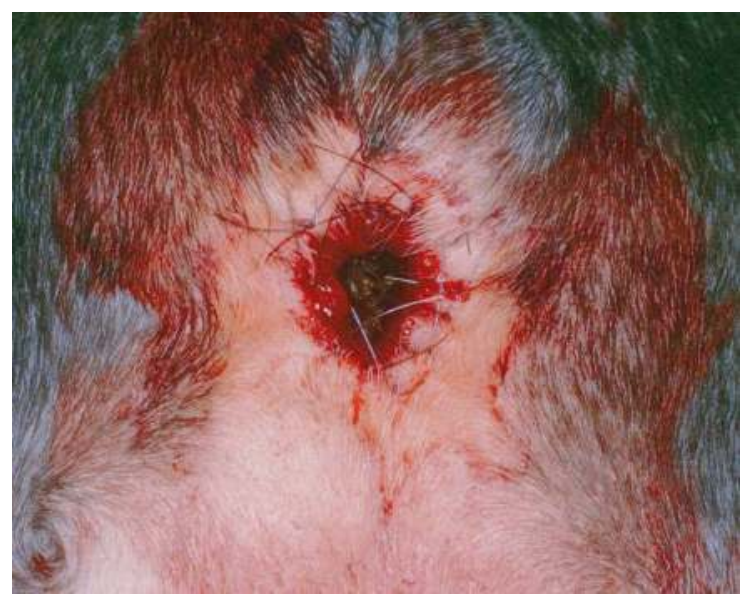

Fig. 19. Anoplasty in the dog of figure 8 with atresia ani type I. 
sphincter and anal sacs (Hosgood \& Hoskins, 1998; Aronson, 2003; Prassinos et al., 2003; Ellison \& Papazoglou, 2011). Type I atresia ani may also be treated with bougienage or balloon dilatation in a single or multiple treatments; however, failures are not uncommon (Hosgood \& Hoskins, 1998; Webb et al., 2007; Tomsa et al., 2011; Ellison \& Papazoglou, 2011). Recently, a single balloon dilatation procedure alone or combined with intralesional triamcinolone injection was used to successfully treat type I atresia ani in 5 kittens and two dogs (Webb et al., 2007; Tomsa et al., 2011). Prospective studies are needed to evaluate balloon dilatation for the treatment of congenital anorectal strictures in small animals.

\subsection{Type II \& III atresia ani}

For animals with type II or III atresia ventral recumbency is used and a cruciate, vertical or vertical elliptical incision is made over the anal dimple and medial to the ducts of the anal sacs. The triangular flaps or elliptical skin created are excised. The external sphincter and distal rectal pouch are identified and dissection is continued medial to the sphincter using fine scissors. The rectum is mobilized through the sphincter by using stay sutures, opened and sutured to the subcutaneous tissue and skin with 4/0-5/0 monofilament absorbable or non absorbable suture material respectively (Figures 20-22). In some animals with Type III atresia ani the rectal pouch is located more than $1 \mathrm{~cm}$ away from the anal dimple dissection for identification and mobilization of the rectum is achieved through rectal pull through procedure. The colon and rectum should be evacuated from feces before recovery, while the animal is still in anesthesia, to promote normal intestinal function (Hosgood \& Hoskins, 1998; Aronson, 2003; Prassinos et al., 2006; Ellison \& Papazoglou, 2011).

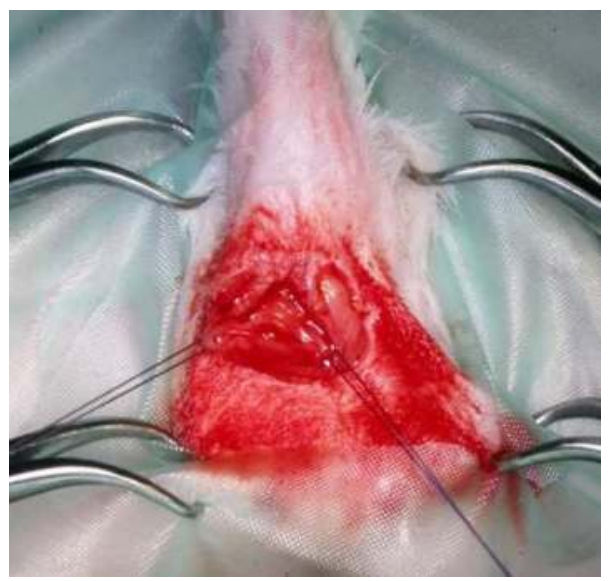

Fig. 20. The rectal pouch was identified through a cruciate incision made over the anal dimple in a puppy of figure 9 . Two stay sutures were placed in the rectum to allow easy handling. 


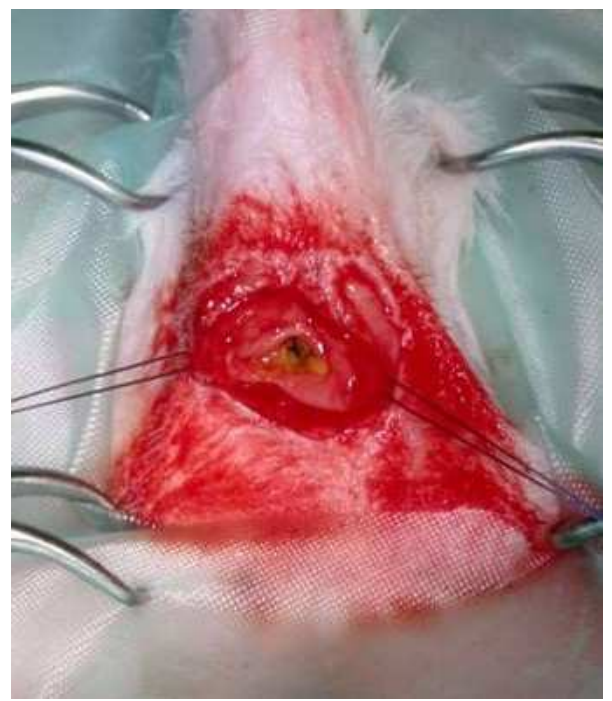

Fig. 21. The rectum of the dog of figure 9 was mobilized and opened to allow an anoplasty procedure.

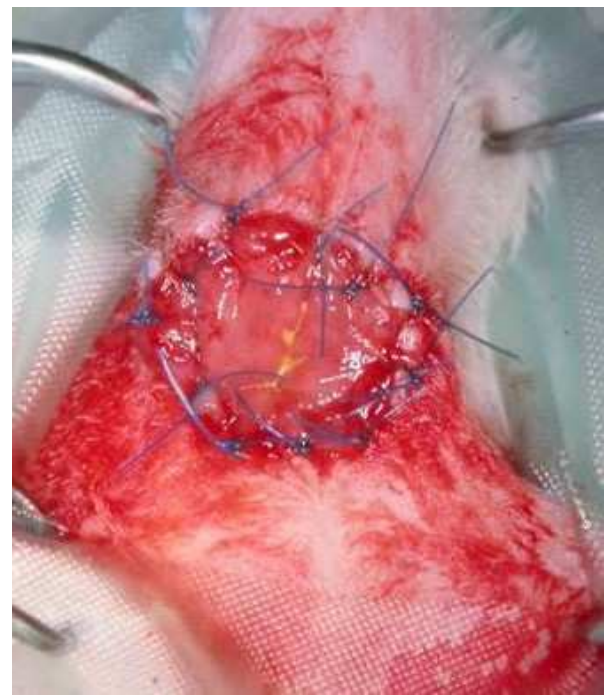

Fig. 22. The rectal mucosa of the dog of figure 9 was sutured to the skin with simple interrupted nylon sutures to complete the anoplasty.

\subsection{Type IV atresia ani}

Animals with this type of atresia may need an abdominal approach to isolate, mobilize and anastomose the cranial colon with the distal colon and rectum usually through a pubic symphisiotomy procedure (Hosgood \& Hoskins, 1998; Aronson, 2003). 


\subsection{Types II-III atresia ani with rectovaginal fistula}

Three surgical techniques are used for the correction of rectovaginal fistula in dogs and cats. Initial approach is through a vertical midline perineal incision extending from the ventral anus to the vulva. In one technique the fistula is isolated, excised and the rectal and vulvar lumens are ligated or oversewn separately with 3/0 -4/0 monofilament absorbable suture material or hemostatic clips followed by closure of the vertical perineal incision; An anoplasty procedure for atresia correction as previously described is performed afterwards (Chambers, 1986; Hosgood \& Hoskins, 1998; Aronson, 2003; Prassinos et al., 2003; Viana \&Tobias, 2005; Rahal et al., 2007; Ellison \& Papazoglou, 2011). Fistula obliteration by performing numerous purse-string sutures placed along its length was also described in a dog (Louw \& van Schouwenburg, 1982). According to another technique, used in 3 cats and $1 \mathrm{dog}$, the rectum is transected cranial to the fistulous opening, the affected rectal portion is excised and the terminal part of the rectum is sutured to the anus (Rawlings \& Capps, 1971; Suess et al., 1992; Aronson, 2003). In the third technique the fistulous tract is preserved, isolated, mobilized through the anus and sutured to the skin at the level of the external anal sphincter; this technique was used for anal reconstruction in 2 dogs (Prassinos et al., 2003; Ellison \& Papazoglou, 2011) and 1 cat (Bornet, 1990) and modified to be performed in 2 dogs through an episiotomy approach (Mahler \&Williams, 2005) [Figures 23-25]. With this technique the preserved fistulus tract is considered the terminal part of the rectum and thus function of the internal anal sphincter is maintained (Prassinos et al., 2003; Mahler \& Williams, 2005).

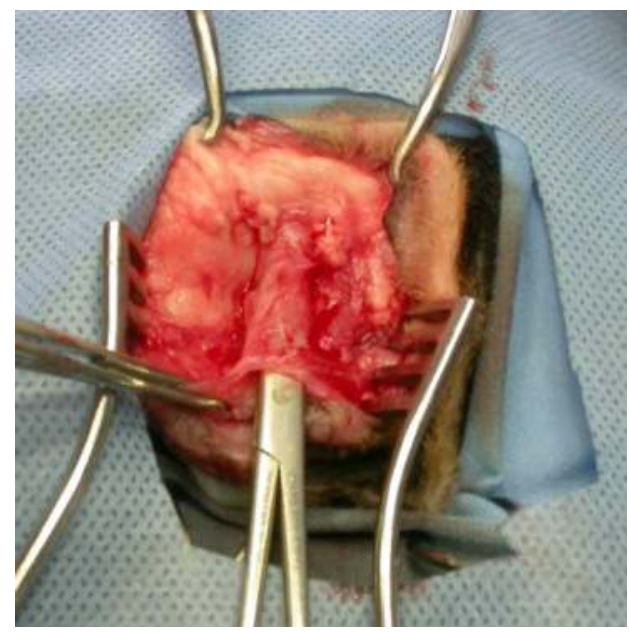

Fig. 23. Atresia ani type III associated with a rectovaginal fistula. The fistulous tract of the dog of figure 12 was isolated through a vertical midline perineal incision extending from the anus to the vulva. A pair of closed needle holders was inserted through the tract. 


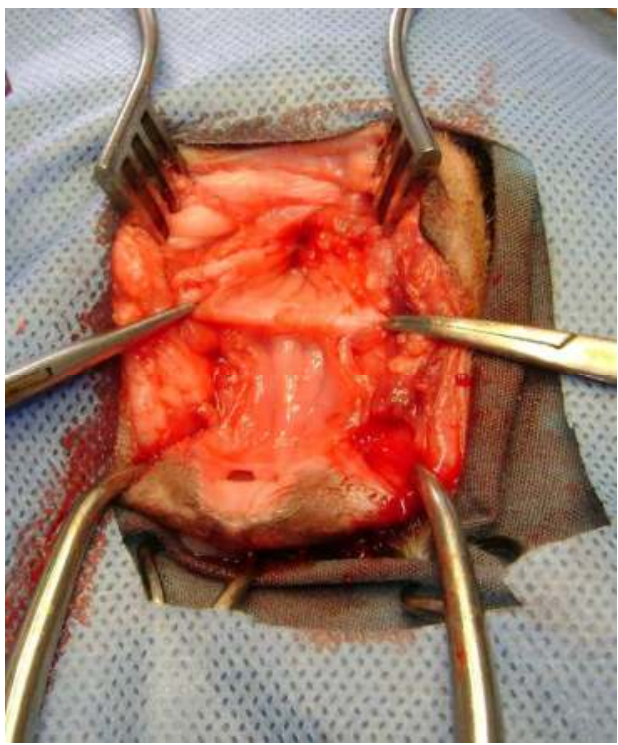

Fig. 24. Atresia ani type III associated with a rectovaginal fistula. The fistulous tract grasped with mosquito hemostats was dissected from the vagina.

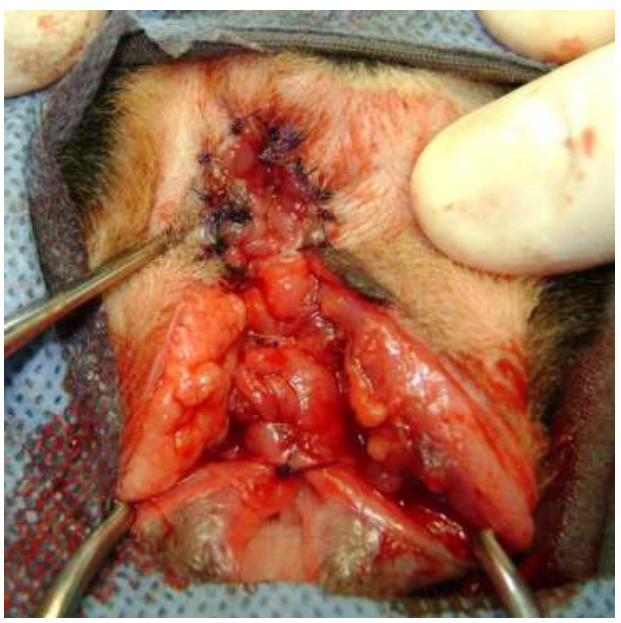

Fig. 25. Atresia ani type III associated with a rectovaginal fistula. The fistulous tract was sutured to the external anal sphincter and the vaginal mucosa was closed with simple interrupted sutures.

\subsection{Temporary end-on colostomy for the management of cats with rectocutaneous fistulas associated with type II atresia ani}

Temporary incontinent end-on colostomy may be performed initially for fecal diversion to help eliminate rectocutaneous fistulas. Colostomy is located in the lateroventral abdominal 
wall. Soon after colostomy and following resolution of fistulas a second surgery is performed for colostomy closure and reconstruction of the atresia ani by performing anoplasty (Tsioli et al., 2009) [Figures 26 \& 27].

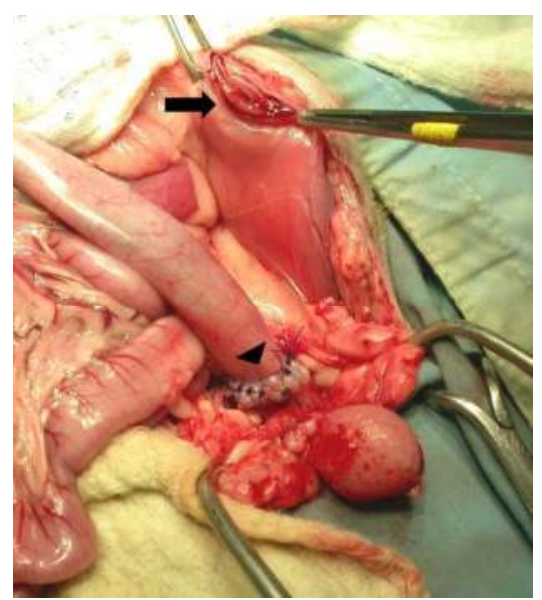

Fig. 26. Following resolution of fistulas the colostomy was closed (arrow) and an end to end colocolonic anastomosis was performed (arrowhead) through a ventral midline celiotomy in a cat.

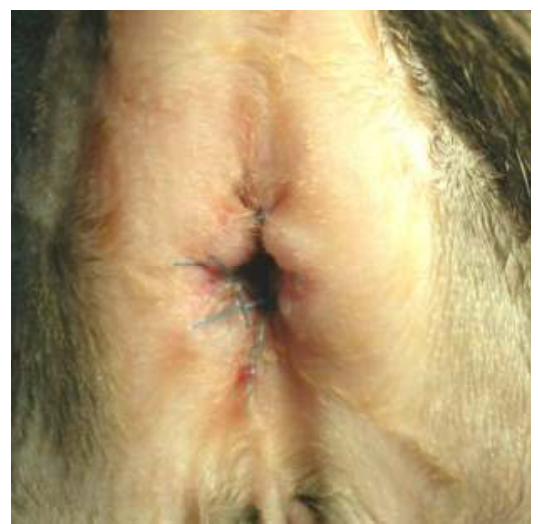

Fig. 27. Atresia ani reconstruction through anoplasty was performed following colostomy closure in a cat.

\section{Postoperative care}

Postoperatively analgesia through opioid administration for a week's time, cisapride to promote colonic motility and stool softeners as lactulose to combat constipation are provided. Fecal impaction may be relieved manually and multiple enemas should be avoided. Many animals start to defecate soon after surgery (Prassinos et al., 2003; Rahal et al., 2007; Ellison \& Papazoglou, 2011). 


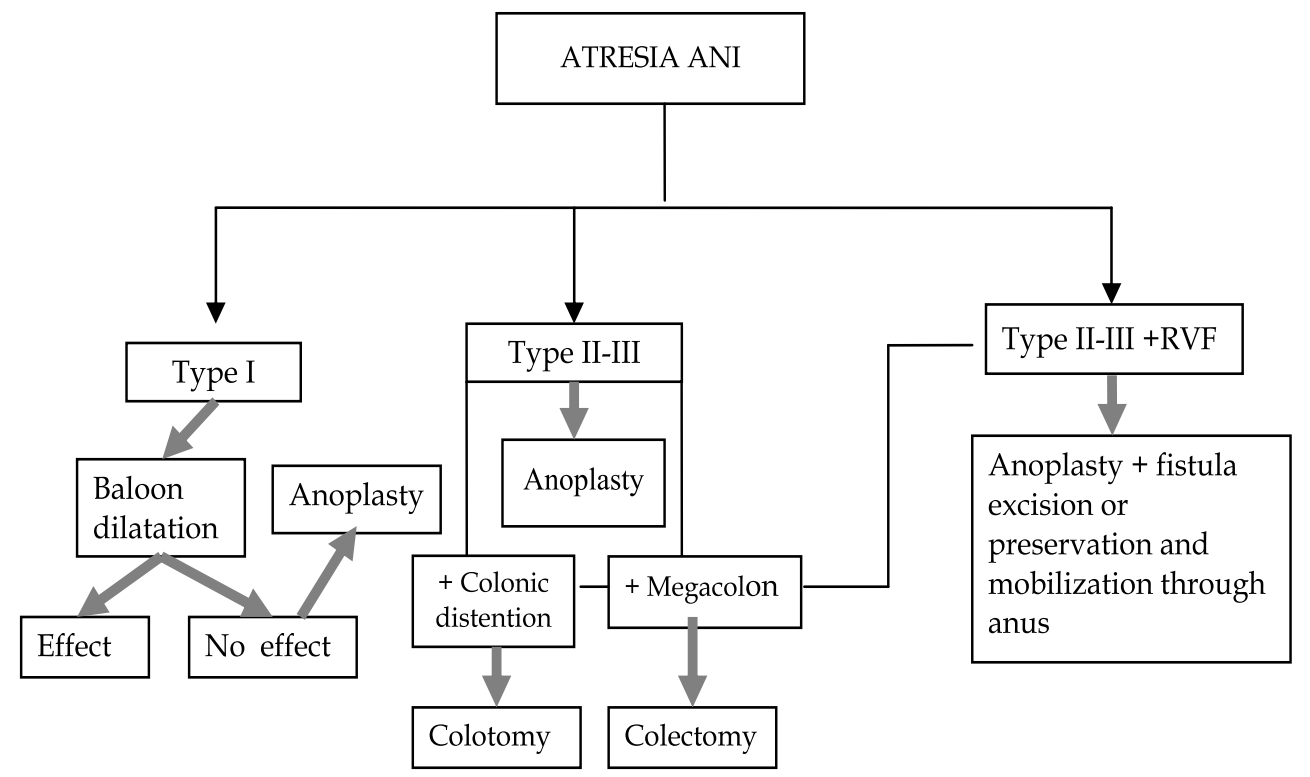

Table 2. Algorithm for atresia ani treatment methods in dogs and cats. RVF : rectovaginal fistula

\section{Complications}

Postoperative complications may include tenesmus, fecal incontinence, wound dehiscence, stricture of the anoplasty, colonic atony or megacolon and rectal prolapse (Suess et al., 1992; Prassinos et al., 2003; Vian \& Tobias, 2005; Rahal et al., 2007; Ellison \& Papazoglou, 2011). Fecal incontinence, a common complication after surgery, may be transient (Prassinos et al., 2003; Viana \& Tobias, 2005, Rahal et al., 2007), intermittent or permanent (Suess et al., 1992; Ellison \& Papazoglou, 2011) and related to a congenital absence of functional external anal sphincter or surgical trauma to the sphincter muscle innervation during dissection (Aronson, 2003; Prassinos et al., 2003; Viana \& Tobias, 2005; Ellison \& Papazoglou, 2011). Fecal incontinence secondary to surgical intervention in dogs may resolve several weeks to a year after surgery (Prassinos et al., 2003; Viana \& Tobias, 2005; Rahal et al., 2007). Semitendinosus muscle flap application was proposed as an option to improve anal tone in a dog with atresia ani and rectovaginal fistula (Chambers \& Rawlings, 1991). Wound dehiscence may be related to tension on the anastomosis and fecal contamination of the surgical site (Suess et al., 1992) and may be prevented by meticulous surgical technique. Stricure of the anoplasty site and fecal retention associated with colonic atony or megacolon are two common complications requiring a second surgery such as revision anoplasty, subtotal colectomy or colotomy (Viana \& Tobias, 2005, Ellison \& Papazoglou, 2011). Animals with stricture of the anoplasty site may develop tenesmus, constipation and fecal impaction. This complication may need a revision anoplasty or baloon dilatation to resolve. In a recent study with 12 cases of dogs and cats with atresia ani having surgical management, 5 animals with type II-III atresia ani, 4 of which combined with rectovaginal fistula, developed postoperative stricture and had initially balloon dilatation, which failed in all but one case. 
Of these failures 5 had revision anoplasty which was successful in 4 animals and 3 had concurrent colotomy for fecal impaction removal, all with good results (Ellison \& Papazoglou 2011). Subtotal colectomy that was performed in one dog with type II atresia ani 2 weeks after anoplasty continued to show constipation associated with megacolon 9 months after surgery (Viana \& Tobias, 2005). Colotomy or subtotal colectomy might be performed at the same time with anoplasty to help improve colonic function in animals with colonic dilatation or megacolon.

\section{Outcome and prognosis}

In the larger study reported to date 10 of 12 dogs with type I and II atresia ani survived long term with survival times ranged from 12-96 months and 6 of the 8 animals were continent. In contrast 2 of the 3 animals having type III atresia ani were euthanized because of continuous tenesmus (Ellison \& Papazoglou, 2011).

\section{Comparative aspects of atresia ani}

Anorectal malformations represent a wide spesctrum of disorders in boys and girls associated with urogenital tract, sacral or spinal defects. These defects are grouped in anatomic categories sharing similar prognosis and management. Treatment of these anorectal malformations aims at anatomical reconstruction, diagnosis and treatment of any associated defects and provides patients with good quality of life by addressing the functional sequelae of these malformations (Pena \& Hong, 2000). The most common defect in males include imperforate anus with rectourethral fistula; some of these fistulas are associated with good quality muscles, well developed sacrum and anal dimple whereas some others are related with poor quality muscles, abnormally developed sacrum and hardly visible dimple. The most common defect in females is rectovestibular fistula and this anomaly has excellent functional prognosis (Levitt \& Penna, 2005). About $75 \%$ of the patients with anorectal malformations will pass voluntary bowel motions and enjoy a good quality of life postoperatively, while constipation urinary and fecal incontinence are common complications following anorectal reconstruction (Pena \& Hong, 2000).

\section{References}

Amand, W. (1974). Nonneurogenic disorders of the anus and rectum. Veterinary Clinics of North America, Vol. 4, No. 3, (August 1974), pp. 535-550

Aronson, L. (2003). Rectum and Anus, In: Textbook of Small Animal Surgery, D. Slatter, (Ed), 682-708, Saunders, ISBN 0721686079, Philadelphia, USA

Bornet, J. (1990). Fistule recto-vaginale et imporforation anale chez une chatte: traitment chirurgical. Bulletin de l'Academie Veterinaire de France, Vol. 63, No. 1, (JanuaryMarch 1990), pp. 53-65

Bright, R. \& Bauer M. (1994). Surgery of the digestive system, In: The Cat Diseases and Clinical Management, R. Sherding, (Ed), 1353-1401, Churchill Livingstone, ISBN 0443088799, New York, USA

Brown, C., Baker, D. \& Barker, I. (2007). Alimentary system, In: Jubb, Kennedy and Palmer's Pathology of Domestic Animals, M. Maxie (Ed), ISBN 13978070202785, Saunders, Edinburgh, UK 
Chambers, J. (1986). Surgical diseases of the anorectum, In: Canine and Feline Gastroenterology, B. Jones (Ed), 279-294, Saunders, ISBN 0721652069, Philadelphia, USA

Chandler, J. \& MacPhail, C. (2001). Congenital urethrorectal fistulas. Compendium on Continuing Education for the Practicing Veterinarian, Vol. 23, No. 11, (November 2001), pp. 995-1002

Ellison, G. \& Papazoglou, L. (2011). Long-term results of surgery for atresia ani in small animals-12 cases. Journal of the American Veterinary Medical Association, n.d.

Greiner, T. (1972). Surgery of the rectum and anus. Veterinary Clinics of North America, Vol. 2, No. 1, (January 1972), pp. 167-180

Holt, P. (1985). Anal and perianal surgery in dogs and cats. In Practice, Vol. 7, No. 3, (May 1985), pp. 82- 89

Hosgood, G. \& Hoskins, J. (1998). Abdominal cavity and gastrointestinal disorders, In: Small Animal Paediatric Medicine and Surgery, G. Hosgood \& J. Hoskins (Eds), 68-114, Butterworth Heinemann, ISBN 0750635991, Woburn, USA

Kilic, N. \& Sarierler, M. (2004). Congenital intestinal atresia in calves. Revue de Medecine Veterinaire, Vol. 155, No. 7 (July 2004), pp. 381-384

Knecht, C. \& Westerfield, C. (1971). Anorecto-urogenital anomalies in a dog. Journal of the American Veterinary Medical Association, Vol. 159, No. 1 (July 1971), pp. 91-92

Levitt, M. \& Pena, A. (2005). Outcomes from the correction of anorectal malformations. Current Opinion in Pediatrics, Vol. 17, No.3, (June 2005), pp. 394-401

Louw, G. \& van Schouwenburg, J. (1982). The surgical repair of atresia ani in a dobermann bitch. Journal of the South African Veterinary Association, vol. 53, No. 2, (June 1982), pp. 119-120

Mahler, S. \& Williams, G. (2005). Prerservation of the fistula for reconstruction of the anal canal and the anus in atresia ani and rectovestibular fistula in 2 dogs. Veterinary Surgery, Vol.34, No. 2, (March-April 2005), pp. 148-152

Partlow, G., Fisher, K., Page, P., MacMilan, K. \& Walker, A. (1993). Prevalence and types of birth defects in Ontario swine determined by mail survey. Canadian Journal of Veterinary Research, Vol. 57, No. 2, (April 1993), pp. 67-73

Pena, A. \& Hong, A. (2000). Advances in the management of anorectal malformations. The American Journal of Surgery, Vol. 180, No. 11, (November 2000), pp. 370-376

Prassinos, N., Papazoglou,L., Adamama-Moraitou, K., Galatos, A., Gouletsou, P. \& Rallis, T. (2003). Congenital anorectal abnormalities in six dogs. Veterinary Record, Vol.153, No. 3, (July 2003), pp. 81-85

Rahal, S., Vicente, C., Mortari, A., Mamprim, M. \& Caporalli, E. (2007). Rectovaginal fistula with atresia ani in 5 dogs. Canadian Veterinary Journal, Vol. 48, No. 8, (August 2007), pp. $827-830$

Rawlings, C. \& Capps, W. (1971). Rectovaginal fistula and imperforate anus in a dog. Journal of the American Veterinary Medical Association, Vol. 159, No. 3, (August 1971), pp. 320-326

Sadler, T. (1995). Digestive system, In: Langman's Medical Embryology, T. Sandler (Ed), 242-271, Williams and Wilkins, ISBN 068307489X, Baltimore, USA

Suess, R., Martin, R., Moon, M. \& Dallman, M. (1982). Rectovaginal fistula with atresia ani in three kittens. Cornell Vet, Vol. 82, No. 2, (April 1992), pp. 141-153 
Tomsa, K. , Major, A. \& Galus, T. (2011). Treatment of atresia ani type I by balloon dilatation in 5 kittens and one puppy. Schweizer Archiv fur Tierheilkunde, Vol. 153, No. 6, (June 2011), pp. $277-280$

Tsioli, V., Papazoglou, L., Anagnostou, T., Kouti, V. \& Papadopoulou, P. (2009). Use of a temporary incontinent end-on colostomy in a cat for the management of rectocutaneous fistulas associated with atresia ani. Journal of Feline Medicine and Surgery, Vol. 11, No. 12, (Dec 2009), pp. 1011-1014

Van den Broek, A., Else, R. \& Hunter, M. (1988). Atresia ani and urethrorectal fistula in a kitten. Journal of Small Animal Practice, Vol. 29, No. 2, (February 1988), pp. 91-94

Vianna, M. \& Tobias, K. (2005). Atresia ani in the dog: a retrospective study. Journal of the American Animal Hospital Association, Vol. 41, No. 5. (September-October 2005), pp. 317-322

Webb, G., McCord, K. \& Twedt, D. (2007). Rectal stricture in 19 dogs: 1997-2005. Journal of the American Animal Hospital Association, Vol. 43, No. 6, (November-December 2007), pp. 332-336 


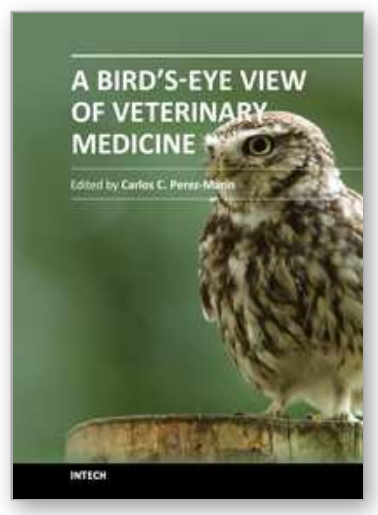

\author{
A Bird's-Eye View of Veterinary Medicine \\ Edited by Dr. Carlos C. Perez-Marin
}

ISBN 978-953-51-0031-7

Hard cover, 626 pages

Publisher InTech

Published online 22, February, 2012

Published in print edition February, 2012

Veterinary medicine is advancing at a very rapid pace, particularly given the breadth of the discipline. This book examines new developments covering a wide range of issues from health and welfare in livestock, pets, and wild animals to public health supervision and biomedical research. As well as containing reviews offering fresh insight into specific issues, this book includes a selection of scientific articles which help to chart the advance of this science. The book is divided into several sections. The opening chapters cover the veterinary profession and veterinary science in general, while later chapters look at specific aspects of applied veterinary medicine in pets and in livestock. Finally, research papers are grouped by specialisms with a view to exploring progress in areas such as organ transplantation, therapeutic use of natural substances, and the use of new diagnostic techniques for disease control. This book was produced during World Veterinary Year 2011, which marked the 250th anniversary of the veterinary profession. It provides a fittingly concise and enjoyable overview of the whole science of veterinary medicine.

\title{
How to reference
}

In order to correctly reference this scholarly work, feel free to copy and paste the following:

Lysimachos G. Papazoglou and Gary W. Ellison (2012). Atresia Ani in Dogs and Cats, A Bird's-Eye View of Veterinary Medicine, Dr. Carlos C. Perez-Marin (Ed.), ISBN: 978-953-51-0031-7, InTech, Available from: http://www.intechopen.com/books/a-bird-s-eye-view-of-veterinary-medicine/atresia-ani-in-the-dog-and-cat

\section{INTECH}

open science | open minds

\section{InTech Europe}

University Campus STeP Ri

Slavka Krautzeka 83/A

51000 Rijeka, Croatia

Phone: +385 (51) 770447

Fax: +385 (51) 686166

www.intechopen.com

\section{InTech China}

Unit 405, Office Block, Hotel Equatorial Shanghai

No.65, Yan An Road (West), Shanghai, 200040, China

中国上海市延安西路65号上海国际贵都大饭店办公楼 405 单元

Phone: +86-21-62489820

Fax: $+86-21-62489821$ 
(C) 2012 The Author(s). Licensee IntechOpen. This is an open access article distributed under the terms of the Creative Commons Attribution 3.0 License, which permits unrestricted use, distribution, and reproduction in any medium, provided the original work is properly cited. 